\title{
ANALISIS PERBANDINGAN SEBELUM DAN SESUDAH PENGENAAN TARIF PAJAK PROGRESIF PADA KENDARAAN BERMOTOR BERDASARKAN “THE FOUR MAXIMS" DI KOTA MANADO
}

\author{
Eugenia Rosalie \\ Jantje Tinangon \\ Rudy Pusung \\ Fakultas Ekonomi dan Bisnis Jurusan Akuntansi \\ Universitas Sam Ratulangi \\ email : NiaRantung@gmail.com
}

\begin{abstract}
ABSTRAK
Pajak kendaraan bermotor merupakan salah satu sumber pendapatan yang memberikan kontirbusi penting. Dengan mulai diberlakukannya pajak progresif pada kendaraan bermotor awal tahun 2012 yang berdasarkan Undang-Undang Nomor 28 tahun 2009 tentang Pajak Daerah dan Retribusi Daerah serta Perda Provinsi Sulut Nomor 7 Tahun 2011 tentang Pajak Daerah Provinsi Sulut bahwa kepemilikan kendaraan bermotor pribadi kedua dan seterusnya tarif pajaknya ditetapkan secara progresif. Pada awal diberlakukanya pajak progresif tersebut, banyak masyarakat yang merasa tidak nyaman dan terbebani, mungkin hal ini disebabkan karena kurangnya informasi mengenai pemberlakuan tarif progresif tersebut. Adapun tujuan dari penelitian ini adalah bagaimana pengenaan tarif progresif pada kendaraan bermotor berdasarkan asas pemungutan pajak di Kota Manado serta mengetahui dampak dari membandingkan sebelum dan sesudah pengenaan. Metode yang digunakan adalah metode deskriptif analitis, yaitu suatu metode penelitian dengan mengungkapkan masalah yang ada di Kantor pemerintahan, mengolah data, menganalisis, meneliti dan menginterprestasikan serta membuat kesimpulan dan memberi saran yang kemudian disusun pembahasannya secara sistematis sehingga masalah yang ada di perusahaan dapat dipahami. Hasil penelitian dapat dilihat pengenaan pajak progresif masih sangat sesuai dengan "The Four Maxims"yaitu asas pemungutan pajak yang dikemukakan oleh Adam Smith yang terdiri dari kesamaan dan keseimbangan (Equality), kepastian hukum (certainty); (c) asas tepat waktu (convenient of payment); dan (d) asas economic of collection.pajak progresif memiliki dampak positif lainnya yaitu meningkatkan penerimaan PKB dan BBNKB yang dengan otomatis meningkatkan penerimaan PAD yang sebagian besar memang merupakan sumber dari Pajak Daerah. Pengenaan Tarif Pajak Progresif sudah berjalan sebagaimana tujuan awal pemerintah memberlakukannya dan sangat sesuai dengan fungsi pajak yaitu Fungsi Budgetair.
\end{abstract}

Kata kunci : pajak kendaraan bermotor, tarif pajak progresif, the four maxims.

\begin{abstract}
Motor vehicle tax is one source of revenue that provides kontirbusi important. With the entry into force of a progressive tax on motor vehicles beginning in 2012 based on Law No. 28 of 2009 on Regional Taxes and Levies as well as the North Sulawesi Provincial Regulation No. 7 of 2011 on Local Taxes North Sulawesi province that both private vehicle ownership and tax rates set forth progressively. At the beginning of the adoption of the progressive tax, many people who feel uncomfortable and overwhelmed, perhaps this was due to lack of information regarding the application of progressive rates. The purpose of this study is how the progressive tariffs on motor vehicles based principle of taxation in the city of Manado, and determine the impact of comparing before and after imposition. The method used is descriptive analytical method, which is a research method to reveal the existing problems in office administration, data processing, analyzing, researching and interpret and make conclusions and give suggestions which are then arranged in a systematic discussion so that problems that exist in the company can be understood. From the results of the research can be seen still highly progressive taxation in accordance with "The Four Maxims" that principle of taxation proposed by Adam Smith which consists of similarity and balance (Equality), legal certainty (certainty), (c) a timely basis (convenient of payment), and (d) the principle of economies of collection. progressive taxation has other positive effects which increase the acceptance of PKB and BBNKB which automatically increases the acceptance of the PAD that most of it is the source of Local Taxes. Imposition of Tax Rate has been running as a Progressive government enforce the original purpose and is in accordance with the tax function is budgetair function.
\end{abstract}

Keywords : motor vehicles tax, progresive tax rate, the four maxims 


\section{PENDAHULUAN}

\section{Latar Belakang}

Pajak merupakan alat bagi pemerintahan dalam mencapai tujuan untuk mendapatkan peneriamaan baik yang bersifat langsung maupun tidak langsung untuk membiayai pengeluaran rutin negara serta untuk membiayai pembangunan nasional dan ekonomi masyarakat. Pajak adalah iuran wajib rakyat kepada negara yang manfaatnya tidak dapat secara langsung dirasakan.

Secara teoritis alasan pengenaan pajak kendaraan bermotor (PKB) adalah penggunaan jalan raya yang merupakan barang publik (public goods -tidak murni) oleh masyarakat. Dalam UU No. 28 tahun 2009 tentang Pajak Daerah dan Retribusi Daerah, tarif pajak Kendaraan Bermotor dikenakan secara progresif, yakni 1,5\% terhadap nilai jual untuk pembelian Kendaraan Bermotor pertama dan 2-10\% terhadap kendaraan kedua dan seterusnya. Seiring dengan berlakunya tarif pajak progresif pada kendaraan bermotor yang adalah aturan baru, masyarakat merasa semakin terbebani karena biaya yang dikeluarkan untuk membayar pajak kendaraan semakin bertambah.

Sistem otonomi daerah yang diberlakukan di Indonesia sejak 1 Januari 2007, menuntut daerah- daerah mencari baerbagai alternatif sumber penerimaan yang dapat digunkan membiayai pengeluaran dan belanja daerah. Pemberian kewenangan kepada daerah untuk memungut pajak dan retribusi daerah diperlukan adanya landasan hukum yang merupakan dasar hukum pemungutan pajak Daerah dan Retribusi Daerah yaitu UndangUndang No. 18 Tahun 1977 tentang Pajak Daerah dan Retribusi Daerah sebagaimana telah diubah menjadi Undang- Undang No. 28 Tahun 2009 yang berlauk sejak Januari 2010 (Waluyo,2011:23).

Peranan pemerintah daerah dalam penyelenggaran pemerintah dan pembangunan serta pelayanan masyarakat dalam pelaksanaan otonomi daerah akan semakin meningkat, peningkatan peranan ini dilandasi dengan kemampuan daerah untuk mengelola secara optimal potensi daerahnya sendiri termasuk dalam pengelolaan sumber- sumber Pendapatan Asli.

Sesuai dengan tujuan ditambahkannya tarif pajak progresif adalah untuk mengurangi antusiasme masyarakat terhadap pembelian kendaraan bermotor dan untuk meningkatkan sumber penerimaan negara. Tujuan pemerintah ini sesuai dengan fungsi pajak itu sendiri yaitu Fungsi Regulerend atau mengatur dan Fungsi Budgetair. Seiring dengan berlakunya tarif pajak progresif pada kendaraan bermotor, penulis ingin mengetahui efektifitas dari tujuan pemerintah tersebut. Apakah sudah seuai dengan kedua fungsi tersebut.

\section{Tujuan Penelitian}

Tujuan yang ingin dicapai dala penelitian ini adalah :

1. Untuk mengetahui penerapan tarif pajak progresif pada kendaraan bermotor di Kota Manado.

2. Untuk mengetahui penerapan tarif pajak progresif pada kendaraan bermotor berdasarkan asas-asas pemungutan pajak.

3. Untuk mengetahui efektifitas tujuan pengenaan pajak progresif terhadap fungsi dari pajak yaitu sebagai Budgetair atau Regulerend.

\section{TINJAUAN PUSTAKA}

\section{Pajak}

Pajak Menurut Pasal 1 angka 1 UU No.28 th 2007 tentang Ketentuan Umum dan Tata Cara Perpajakan: "Pajak adalah kontribusi wajib kepada negara yang terutang oleh orang pribadi atau badan yang bersifat memaksa berdasarkan Undang-Undang, dengan tidak mendapatkan imbalan secara langsung dan digunakan untuk keperluan negara bagi sebesar-besarnya kemamakmuran rakyat"

Muljono ( 2009 : 1) menyatakan bahwa pajak adalah iuran kepada kas negara yang dapat dipaksakan yang terutang oleh yang wajib membayarnya menurut peraturan-peraturan dengan tidak mendapat prestasi kembali yang langsung dapat ditunjuk dan gunanya adalah untuk membiayai pengeluaran-pengeluaran umum yang berhubungan dengan tugas negara yang menyelenggarakan pemerintahan. 
Soemitro dalam Mardiasmo (2011:1) menyatakan bahwa pajak adalah iuran rakyat kepada kas negara berdasarkan undang-undang (yang dapat dipaksakan) dengan tidak mendapat jasa timbal (kontraprestasi), yang langsung dapat ditunjukkan dan yang digunakan untuk membayar pengeluaran umum, dengan penjelasan sebagai berikut: "dapat dipaksakan" artinya: bila utang pajak tidak dibayar, utang itu dapat ditagih dengan menggunakan kekerasan, seperti surat paksa dan sita, dan juga penyanderaan terhadap pembayaran pajak, tidak dapat ditunjukkan jasa timbal balik tertentu seperti halnya dengan retribusi.

Andriani dalam bukunya Waluyo,(2011 : 2) menyatakan pajak adalah iuran masyarakat kepada Negara (yang dipaksakan) yang terutang oleh yang wajib membayarnya menurut peraturan-peraturan umum (undangundang) dengan tidak mendapat prestasi kembali yang langsung dapat ditunjuk dan yang gunanya adalah untuk membiayai pengeluaranpengeluaran umum berhubung tugas Negara untuk menyelenggarakan pemerintahan.

\section{Unsur Pajak}

1. Pajak merupakan iuran wajib dari rakyat kepada kas negara yang berupa uang.

2. Pajak bersifat memaksa karena pemungutannya berdasarkan dengan undang-undang.

3. Dalam pembayaran pajak tidak dapat langsung dirasakan manfaatnya.

4. Digunakan untuk membiayai rumah tangga negara, yakni pengeluaran- pengeluaran yang bermanfaat bagi masyarakat luas.Unsur Pajak

\section{Fungsi Pajak}

1. Fungsi Budgetair/Finansial

Dalam fungsi budgetair ini pajak digunakan untuk membiayai keperluan keperluan rutin negara, seperti pembangunan, pembelanjaan rumah tangga negara, pembayaran gaji pegawai negeri sipil, dll.

2. Fungsi Regulerend/Mengatur

Dalam fungsi regulerend atau fungsi mengatur ini pajak digunakan sebagai alat untuk mengatur baik masyarakat baik di bidang ekonomi, sosial, maupun politik dengan tujuan tertentu dengan mengunakan kebijakan pajak.

\section{Jenis Pajak}

Jenis pajak dapat digolongkan menjadi 3 macam yaitu:

1. Menurut Golongannya :

a. Pajak Langsung adalah pajak yang bebannya harus ditanggung sendiri oleh Wajib Pajak yang bersangkutan dan tidak dapat dibebankan kepada pihak lain.

b. Pajak Tidak Langsung adalah pajak yang bebannya dapat dilimpahkan kan atau dibebankan kepada pihak lain.

2. Berdasarkan Lembaga pemungut :

a. Pajak Pusat/Pajak Negara adalah pajak yang lembaga pemungut yang berwenang ada pada pemerintah pusat yang pelaksanaannya dilakukan oleh Departemen Keuangan melalui Direktorat Jendral Pajak. Contohnya : Pajak penghasilan, Pajak Pertambahan Nilai dan Pajak Penjualan atas Barang Mewah, Pajak Bumi dan Bangunan, dan Bea Materai.

b. Pajak Daerah adalah pajak yang lembaga pemungut yang berwenang ada pada pemerintah daerah yang pelaksanaannya dilakukan oleh Dinas Pendapatan Daerah. Dalam Undang-undang No. 28 Tahun 2009 tentang Pajak Daerah dan Retribusi Daerah, terdiri dari 5 jenis Pajak Daerah Propinsi dan 11 jenis Pajak Daerah Kabupaten/Kota.

3. Berdasarkan Sifat

a. Pajak Subjektif adalah pajak yang memperhatikan kondisi/keadaan Wajib Pajak. Dalam menentukan pajaknya harus ada alasan-alasan objektif yang berhubungan erat dengan keadaan materialnya yaitu gaya pikul.

b. Pajak Objektif adalah pajak yang pada awalnya memerhatikan objek yang menyebabkan timbulnya kewajiban membayar, kemudian baru dicari subjeknya baik Orang Pribadi maupun badan. Jadi dengan kata lain, pajak objektif adalah pengenaan pajak yang hanya memerhatikan kondisi objeknya saja. 


\section{Tarif Pajak}

Tarif pajak didefinisikan sebagai angka tertentu yang digunakan sebagai dasar pengenaan pajak, yaitu (Mardiasmo,2009:9) :

1. Tarif Sebanding/Proporsional yaitu tarif berupa persentase yang tetap, terhadap berapapun jumlah yang dikenai pajak sehingga besarnya pajak yang terutang proporsional terhadap besarnya nilai yang dikenai pajak.

2. Tarif Tetap yaitu tarif berupa jumlah yang tetap (sama) terhadap berapapun jumlah yang dikenai pajak sehingga besarnya pajak yang terutang tetap.

3. Tarif Progresif yaitu persentase tarif yang digunakan semakin besar bila jumlah yang dikenai pajak semakin besar. Menurut kenaikan persentase tarifnya, tarif progresif dibagi:

a. Tarif progresif progresif : kenaikan persentase semakin besar

b. Tarif progresif tetap : kenaikan persentase tetap

c. Tarif progresif degresif : kenaikan persentase semakin kecil

4. Tarif Degresif yaitu tarif yang digunakan semakin kecil bila jumlah yang dikenai pajak semakin besar.

\section{Asas- asas Pemungutan Pajak}

Sekitar abad 18 seorang ahli Ekonomi yang kini disebut sebagai Bapak Ekonomi yaitu Adam Smith (1723-1790) dalam bukunya An Inquiry into the Nature and Causes of the Wealth of Nations (terkenal dengan nama Wealth of Nations) mengemukakan empat asas pemungutan pajak yang lazim disebut "The Four Cannons Maxims Taxation". Suatu aturan hukum tentang pajak yang adil harus memenuhi syarat yaitu

a. Asas kesamaan (equality) dan keadilan (equity)

b. Asas kepastian hukum (certainty)

c. Asas tepat waktu (convenient of payment)

d. Asas economic of collection yang mengharuskan biaya pemungutan pajak harus relatif kecil dibandingkan dengan pajak yang masuk.

\section{Pajak Daerah}

Berdasarkan peraturan daerah Propinsi Sulawesi Utara tentang Pajak Daerah Bab 1 Ketentuan Umum, Pajak Daerah yang selanjutnya disebut pajak adalah kontribusi wajib kepada daerah yang terhutang oleh orang pribadi atau badan yang bersifat memaksa berdasarkan Undang-Undang dengan tidak mendapatkan imbalan secara langsung dan digunakan untuk keperluan Daerah bagi sebesar-besarnya kemakmuran rakyat.

\section{Pajak Kendaraan Bermotor}

Beberapa jenis pajak yang diatur dalam pajak daerah salah satunya adalah pajak kendaraan bermotor. Definisi Kendaraan Bermotor berdasarkan UU No 28 tahun 2009 adalah semua kendaraan beroda beserta gandengannya yang digunakan di semua jenis jalan darat, dan digerakkan oleh peralatan teknik berupa motor atau peralatan lainnya yang berfungsi untuk mengubah suatu sumber daya energi tertentu menjadi tenaga gerak kendaraan bermotor yang bersangkutan, termasuk alat-alat berat dan alat-alat besar yang dalam operasinya menggunakan roda dan motor dan tidak melekat secara permanen serta kendaraan bermotor yang dioperasikan di air.

\section{Subjek dan Wajib Pajak}

1. Subjek Pajak Kendaraan Bermotor adalah orang pribadi atau badan yang memiliki dan/atau menguasai kendaraan bermotor.

2. Wajib Pajak Kendaraan Bermotor adalah orang pribadi atau badan yang memiliki kendaraan bermotor.

3. Yang bertanggungjawab atas pembayaran pajak adalah :

a. untuk orang pribadi adalah orang yang bersangkutan, kuasanya atau ahli warisnya.

b. untuk badan adalah pengurus atau kuasanya. 


\section{Dasar Pengenaan dan Cara Menghitung}

Dasar pengenaan Pajak Kendaraan Bermotor adalah hasil perkalian dari 2 (dua) unsur pokok:

1. Nilai Jual Kendaraan Bermotor; dan

2. Bobot yang mencerminkan secara relatif kadar kerusakan jalan dan/atau pencemaran lingkungan akibat penggunaan kendaraan bermotor.

\section{Presentase Tarif Pajak Progresif}

Berikut adalah presentase pengenaan tarif progresif bagi kendaraan bermotor berdasarkan PERDA Sulawesi Utara.

1. Tarif Pajak Kendaraan Bermotor pribadi ditetapkan dengan cara sebagai berikut:

a. Untuk kepemilikan kendaraan bermotor pertama sebesar 1,5\% (satu koma lima persen);

b. Untuk kepemilikan kendaraan bermotor kedua dan seterusnya ditetapkan secara progresif yaitu,

1) kendaraan kepemilikan kedua sebesar $2 \%$ (dua persen);

2) kendaraan kepemilikan ketiga sebesar $2,5 \%$ (dua koma lima persen);

3) kendaraan kepemilikan keempat sebesar 3\% (tiga persen);

4) kendaraan kepemilikan kelima dan seterusnya 3,5\% (tiga koma lima persen).

2. Tarif Pajak Kendaraan Bermotor angkutan umum, ambulans, pemadam kebakaran, sosial keagamaan, lembaga sosial dan keagamaan, Pemerintah/TNI/POLRI, Pemerintah Daerah ditetapkan sebagai berikut.

a. Kendaraan bermotor angkutan umum sebesar $1 \%$ (satu persen).

b. Kendaraan bermotor ambulans, pemadam kebakaran, sosial keagamaan, lembaga sosial dan keagamaan Pemerintah/TNI/POLRI, Pemerintah Daerah sebesar 0,5 \% (nol koma lima persen).

3. Tarif Pajak Kendaraan Bermotor alat-alat berat dan alat-alat besar ditetapkan sebesar 0,2\% (nol koma dua persen).

4. Tarif Pajak Kendaraan Bermotor di air ditetapkan sebesar 1,5\% (satu koma lima persen). 


\section{Peneliti Terdahulu}

\section{Tabel 1 Penelitian Terdahulu}

\begin{tabular}{|c|c|c|c|c|c|}
\hline $\begin{array}{ll}\text { Nama } & \text { Judul } \\
\text { Peneliti/ } & \end{array}$ & Tujuan & $\begin{array}{l}\text { Metode } \\
\text { penelitian }\end{array}$ & Hasil penelitian & Persamaan & Perbedaan \\
\hline
\end{tabular}

Tahun

\begin{tabular}{|c|c|c|c|c|c|c|}
\hline $\begin{array}{l}\text { Nugraha/ } \\
2010\end{array}$ & $\begin{array}{lr}\text { Penerapan } & \text { Pajak } \\
\text { Progresif } & \text { Terhadap } \\
\text { Wajib } & \text { Pajak } \\
\text { Kendaraan } & \\
\text { Bermotor } & \\
\text { Berdasarkan } & \\
\text { Peraturan Daerah } \\
\text { Jawa Timur Nomor } \\
\text { Tahun 2010 tentang } \\
\text { Pajak Daerah }\end{array}$ & $\begin{array}{l}\text { Bertujuan } \\
\text { untuk } \\
\text { mengetahui } \\
\text { penerapan } \\
\text { pajak } \\
\text { Progresif } \\
\text { terhadap wajib } \\
\text { pajak } \\
\text { kendaraan } \\
\text { bermotor } \\
\text { berdasarkan } \\
\text { peraturan } \\
\text { daerah Jawa } \\
\text { Timur Nomor } \\
9 \text { tahun } 2010 \\
\text { tentang pajak } \\
\text { daerah. }\end{array}$ & $\begin{array}{l}\text { Pengembangan } \\
\text { deskripsi kasus }\end{array}$ & $\begin{array}{l}\text { Penerapan Pajak } \\
\text { Progresif untuk } \\
\text { Kendaraan } \\
\text { Bermotor } \\
\text { menimbulkan } \\
\text { dampak positif } \\
\text { dan negatif. } \\
\text { Dampak positif } \\
\text { yaitu } \\
\text { berkurangnya } \\
\text { jumlah } \\
\text { kendaraan, dan } \\
\text { dampak negatif } \\
\text { masyarakat } \\
\text { melakukan } \\
\text { penyelundupan } \\
\text { hukum. }\end{array}$ & $\begin{array}{l}\text { Peneliti } \\
\text { sebelumnya } \\
\text { melakukan } \\
\text { penelitian } \\
\text { terhadap faktor } \\
\text { yang sama yaitu } \\
\text { tarif pajak } \\
\text { progresif }\end{array}$ & $\begin{array}{l}\text { Peneliti } \\
\text { mencoba } \\
\text { mengkaji } \\
\text { penerepan pajak } \\
\text { progresif } \\
\text { berdasar } \\
\text { peraturan daerah } \\
\text { Jawa Timur } \\
\text { Nomor } 9 \text { tahun } \\
2010\end{array}$ \\
\hline $\begin{array}{l}\text { Fajariani/ } \\
2013\end{array}$ & $\begin{array}{l}\text { Analisis Pengenaan } \\
\text { Tarif Pajak } \\
\text { Progresif Pada } \\
\text { PajakKendaraan } \\
\text { Bermotor } \\
\text { Berdasarkan "The } \\
\text { Four Maxims" }\end{array}$ & $\begin{array}{l}\text { Untuk } \\
\text { mengetahui } \\
\text { penerapan } \\
\text { tarif pajak } \\
\text { progresif pada } \\
\text { kendaraanber } \\
\text { motor di } \\
\text { Provinsi jawa } \\
\text { Timur, apakah } \\
\text { pengenaan } \\
\text { tarif progresif } \\
\text { tersebut } \\
\text { sudahsesuai } \\
\text { dengan asas- } \\
\text { asas } \\
\text { pemungutan } \\
\text { pajak }\end{array}$ & Deskripsi & $\begin{array}{l}\text { Asas dalam "The } \\
\text { Four Maxims" } \\
\text { yang } \\
\text { dikemukakan } \\
\text { oleh Adam } \\
\text { Smithkelihatann } \\
\text { ya masih relevan } \\
\text { untuk diterapkan }\end{array}$ & $\begin{array}{l}\text { Peneliti } \\
\text { melakukan } \\
\text { penelitian } \\
\text { terhadap faktor } \\
\text { yang sama yaitu } \\
\text { tarif pajak } \\
\text { progresif pada } \\
\text { kendaraan } \\
\text { bermotor. }\end{array}$ & $\begin{array}{l}\text { Tempat } \\
\text { dilakukannya } \\
\text { penelitian dan } \\
\text { perubahan } \\
\text { perundang- } \\
\text { undangan. }\end{array}$ \\
\hline
\end{tabular}




\section{METODE PENELITIAN}

\section{Jenis Penelitian}

Penelitian ini menggunakan metode deskriptif (kualitatif), membandingkan sebelum dan sesudah pengenaan tarif pajak progresif pada kendaraan bermotor berdasarkan The Four Maxims, hasil dari pencaraian data- data kemudian akan di analisis dan dideskripsikan kemudian disimpulkan sesuai dengan tujuan penelitian ini.

\section{Tempat dan Waktu Penelitian}

Penelitian ini dilakukan di Kantor UPTD Manado (SAMSAT) jalan 17 Agustus No.123 Kota Manado. Penelitian ini dilangsungkan selama 2 minggu yaitu dari tanggal 23 - 7 Oktober 2013.

\section{Prosedur Penelitian}

Susunan prosedur penelitian yang dilakukan dalam penelitian ini adalah sebagai berikut :

1. Melakukan observasi langsung ke objek penelitian untuk mengetaui gambaran umum mekanisme kegiatan pemungutan pajak yang ditetapkan Kantor. Kemudian ke bagian Humas untuk mendapatkan penjelasan mengenai profil kantor dan jumlah pegawai yang ada.

2. Mengumpulkan data- data yang diperlukan sehubungan dengan penelitian ini untuk menjadikan dasar acauan dalam penelitian.

3. Menganalisi apakah pengenaan tarif pajak progresif pada kendaraan bermotor sudah sesuai dengan asas asas pemungutan pajak atau tidak.

4. Menarik kesimpulan dari hasil penelitian yang dilakukan.

\section{Metode Pengumpulan Data}

\section{a. Data Primer}

Pengumpulan data primer dalam penelitian diperoleh dengan cara wawancara langsung dengan pihak Kantor UPTD Samsat Kota Manado yang bebas terpimpin, yaitu dilakukan dengan mempersiapkan terlebih dahulu pertanyaan- pertanyaan sebagai pedoman, tetapi masih memungkinkan melakukan variasi-variasi pertanyaan yang disesuaikan dengan jawaban dari responden dan situasi ketika wawancara. Dalam hal ini mewawancarai langsung Kepala SIE Pajak UPTD Manado.

b. Data sekunder

Pengumpulan data sekunder dilakukan dengan cara studi kepustakaan yaitu suatu cara untuk mendapatkan data yang terdapat di dalam buku di Perpusatakaan Daerah Kota Manado dan Perpustakaan Fakultas Ekonomi Universitas Sam Ratulangi Kota Manado. Hal ini dilakukan dengan mengumpulkan data melalui penelusuran bahan pustaka, mempelajari dan mengutip dari beberapa sumber data yang ada, studi dokumentasi berkas- berkas dari pejabat Kantor Bersama SAMSAT Kota Manado. Selain itu juga dari penelusuran peraturan perundang- undangan dan penelusuran situs-situs internet yang berkaitan dengan penelitian ini. Seperti buku- buku perpajakan dan Undang Undang atau Perda. Serta berupa laporan realisasi PKB dan BBNKB, laporan perincian jenis Kendaraan Bermotor, dan Laporan Perbandingan Realisasi Penerimaan PAD UPTD Manado.

\section{Metode Analisis Data}

Berdasarkan rumusan tujuan sebelumnya, metode penelitian yang digunakan dalam penelitian ini adalah metode deskriptif analitis, yaitu suatu metode penelitian dengan mengungkapkan masalah yang ada di Kantor pemerintahan, mengolah data, menganalisis, meneliti dan menginterprestasikan serta membuat kesimpulan dan memberi saran yang kemudian disusun pembahasannya secara sistematis sehingga masalah yang ada di perusahaan dapat dipahami . 
Pengertian dari metode deskriptif analitis menurut Sugiyono (2009: 29) adalah "Metode Deskriptif adalah suatu metode yang berfungsi untuk mendeskripsikan atau memberi gambaran terhadap objek yang diteliti melalui data atau sampel yang telah terkumpul sebagaimana adanya tanpa melakukan analisis dan membuat kesimpulan yang berlaku untuk umum ."

\section{HASIL PENELITIAN DAN PEMBAHASAN}

\section{Gambaran Umum Kantor UPTD Manado (SAMSAT)}

UPTD Manado (Samsat) merupakan salah satu dari bagian atau perpanjangan tangan dari Dinas Pendapatan Daerah Provinsi Sulawesi Utara. UPTD Manado merupakan satu dari 15 UPTD yang ada di Provinsi Sulut. Yang membantu Dinas Pendapatan Daerah Provinsi Sulawesi Utara dalam memungut pajak dari masyarakat khususnya untuk Pajak Kendaraan Bermotor dan yang berhubungan dengan PKB tersebut. Berawal dengan adanya Undang-undang Nomor 32 tahun 2004 tentang Pemerintahan Daerah, Undang-undang Nomor 33 tahun 2004 Tentang Perimbangan Keuangan Antara Pemerintah Pusat dan Daerah, Undang-undang Nomor 34 Tahun 2000 Tentang Perubahan Atas Undang-undang Nomor 18 Tahun 1997 Tentang Pajak Daerah dan Retribusi Daerah, serta Peraturan daerah Provinsi Sulawesi Utara Nomor 3 Tahun 2008 yang dijabarkan melalui Peraturan Gubernur Nomor 62 tahun 2008, Struktur Organisasi Dinas Pendapatan Daerah Provinsi Sulawesi Utara dititik beratkan pada kegiatan teknis operasional yang dilaksanakan oleh Unit Pelaksana Teknis Dinas (UPTD).

Dalam menjalankan tugas dan fungsi tersebut UPTD Manado (Samsat) berorientasi pada visi dan misi sebagai berikut :

Visi : "Terwujudnya Pendapatan Asli Daerah (PAD) Sebagai Sumber Utama Anggaran Pendapatan Belanja Daerah (APBD)"

Misi :

1. Meningkatkan pelayanan kepada masyarakat.

2. Mengoptimalkan pemungutan Pendapatan Asli Daerah dan Pengelolaan Dana Perimbangan.

3. Meningkatkan tertib administrasi pengelolaan pendapatan daerah.

4. Mengingkatkan koordinasi dengan mitra kerja.

5. Mengembangkan pemanfaatan informatikan dan telematika pendapatan daerah.

\section{Hasil Penelitian}

1. Pajak progresif untuk kendaraan bermotor mulai berlaku di Sulawesi Utara sejak 1 Januari 2012. Berlakunya Pajak progresif ini merupakan penerapan pasal 8 Undang- Undang Nomor 28 Tahun 2009 tentang Pajak Daerah dan Retribusi Daerah yang pelaksanaannya ditetapkan dalam Peraturan Daerah Provinsi Sulawesi Utara Nomor 7 Tahun 2011 tentang Pajak Daerah. Pajak progresif ini berlaku pada kepemilikan kendaraan bermotor kedua dan seterusnya, kendaraan roda 2 (dua) dan kendaraan roda 4 (empat) kecuali pada kendaraan jenis pick up dan Dumb Truck.

2. Dalam Undang-undang No. 28 Tahun 2009 Pasal 6, disebutkan bahwa tarif Pajak kendaraan bermotor pribadi ditetapkan sebagai berikut:

a. Untuk kepemilikan kendaraan bermotor pertama paling rendah sebesar $1 \%$ (satu persen) dan atau paling tinggi sebesar $2 \%$ (dua persen).

b. Untuk kepemilikan kendaraan bermotor kedua dan seterusnya dapat ditetapkan secara progresif paling rendah $2 \%$ (dua persen) dan paling tinggi 10\% (sepuluh persen).

3. Dalam Pasal 7 Peraturan Daerah Sulawesi Utara Nomor 7 Tahun 2011 tentang Pajak Daerah. Adapun untuk kepemilikan kendaraan bermotor kedua dan seterusnya ditetapkan secara progresif yaitu :

a. Kendaraan kepemilikan pertama sebesar $1,5 \%$ (satu koma lima persen)

b. kendaraan kepemilikan kedua sebesar $2 \%$ (dua persen);

c. kendaraan kepemilikan ketiga sebesar 2,5\% (dua koma lima persen);

d. kendaraan kepemilikan keempat sebesar 3\% (tiga persen);

e. kendaraan kepemilikan kelima dan seterusnya 3,5\% (tiga koma lima persen).

4. Asas -asas pemungutan Pajak yang dikemukakan oleh Adam Smith yaitu The Four Maxims. 


\section{Pembahasan}

\section{Pengenaan Tarif Pajak Progresif Pada Kendaraan Bermotor di Kota Manado}

Penerapannya tarif pajak progresif di Sulawesi Utara sejak 1 Januari 2012. Pemberlakuannya di dasari oleh UU no 28 tahun 2009 tentang Pajak Daerah dan Retribusi Daerah yang pelaksanaanya ditetapkan dalam Peraturan Daerah Provinsi Sulawesi Utara Nomor 7 Tahun 2011 Tentang pajak Daerah. Pajak Progresif Berlaku pada kepemilikan kedua dan seterusnya. Pengenaan tarif pajak progresif sendiri pada 2012 belum begitu maksimal, karena masih pihak pemerintah dan masyarakat masih dalam tahap penyesuaian dengan aturan baru ini. Oleh karena itu pada awalnya, pemerintah memberikan keringanan dengan jalan, masyarakat diperbolehkan mengatur susunan kendaraan yang akan dikenakan pajak progresif. Selanjutnya pengenaan tarif pajak progresif akan disesuaikan dengan urutan tanggal pembelian.Kepemilikan kendaraan bermotor untuk penetapan pajak progresif kendaraan bermotor didasarkan atas nama dan/atau alamat yang sama. Penerapan pajak progresif terhadap kendaraan bermotor ini diharapkan juga mampu meningkatkan Pendapatan Asli Daerah (PAD) kota Manado. Karena dengan meningkatnya jumlah pajak yang harus dibayarkan oleh wajib pajak, tentu saja berpengaruh terhadap PAD kota Manado dan mengurangi minat masyarakat dalam membeli Kendaraan bermotor sehingga kemacetan dalam kota dapat berkurang. Berikut adalah tarif pajak progresif yang berlaku di Sulawesi Utara :

a. Kendaraan kepemilikan pertama sebesar 1,5\% (satu koma lima persen)

b. kendaraan kepemilikan kedua sebesar $2 \%$ (dua persen);

c. kendaraan kepemilikan ketiga sebesar 2,5\% (dua koma lima persen);

d. kendaraan kepemilikan keempat sebesar 3\% (tiga persen);

e. kendaraan kepemilikan kelima dan seterusnya 3,5\% (tiga koma lima persen).

Tabel 2 Contoh Perbandingan Perhitungan Sebelum dan Sesudah Pengenaan Tarif Pajak Progresif pada Kendaraan Bermotor di Kota Manado

\begin{tabular}{|c|c|c|}
\hline $\begin{array}{c}\text { Jenis Kendaraan/ } \\
\text { Tahun }\end{array}$ & $\begin{array}{c}\text { Sebelum Pengenaan } \\
\text { Tarif Pajak Progresif }\end{array}$ & $\begin{array}{l}\text { Sesudah Pengenaan } \\
\text { Tarif Pajak Progresif } \\
\end{array}$ \\
\hline Jazz (2003) & $\begin{array}{l}\text { NJKB X } 1.5 \%= \\
\operatorname{Rp~} 140.000 .000,- \text { X } 1.5 \%=R p \\
2.100 .000,-\end{array}$ & $\begin{array}{l}\text { NJKB X } 1.5 \%= \\
\operatorname{Rp} 140.000 .000,-X 1.5 \%=R p \\
2.100 .000,-\end{array}$ \\
\hline City (2005) & $\begin{array}{l}\text { NJKB X } 1.5 \%= \\
\operatorname{Rp} 126.000 .000,-X 1.5 \%=\mathrm{Rp} \\
1.890 .000,-\end{array}$ & $\begin{array}{l}\text { NJKB X 2\% } \\
\operatorname{Rp} 126.000 .000,- \text { X 2\% } \\
2.520 .000,-\end{array}$ \\
\hline Fortuner (2007) & $\begin{array}{ll}\text { NJKB X } 1.5 \% & = \\
\operatorname{Rp} 271.000 .000,- & X 1.5 \%=R p \\
4.065 .000,- & \end{array}$ & $\begin{array}{ll}\text { NJKB X 2.5\% } & = \\
\operatorname{Rp} 271.000 .000,- & \text { X 2.5\% } \\
6.775 .000,- & \text { Rp }\end{array}$ \\
\hline
\end{tabular}

\section{(Sumber : hasil Olahan Penulis)}

Tabel perhitungan diatas dapat dilihat perbedaan jumlah Pajak yang harus dibayarkan pada sebelum dan sesudah dikenakan tarif pajak progresif.

\section{Pengenaan Tarif Pajak Progresif pada Kendaraan Bermotor Berdasarkan The Four Maxims}

Berdasarkan asas Pemungutan Pajak yang dikemukan oleh Adam Smith, pengenaan tarif pajak progresif masih dianggap relevan berikut adalah penjelasannya :

1. Equality, yaitu pembebanan pajak harus sesuai dengan kemampuan wajib pajak. Berdasarkan asas ini penerapan pemberlakuan tarif pajak progresif bagi kendaraan kedua ini dilakukan karena diasumikan bahwa wajib pajak yang memiliki kendaraan bermotor lebih dari satu maka dapat dikategorikan sebagai kelompok masyarakat yang mempunyai penghasilan lebih dari cukup bahkan bisa dikategorikan berpenghasilan tinggi, sehingga pemungutan pajaknya harus lebih besar. 
2. Certainty, yaitu pembebanan pajak yang ada kepastian hukumnya mengenai pengaturan subjek pajak,objek pajaka dan ketentuan pajak lainnya. Berdasarkan asas ini tarif pajak progresif pada kendaraan bermotor dipungut berdasarkan Peraturan Daerah No. 7 tahun 2011 tentang Pajak Daerah.

3. Menurut asas convenience of payment, pajak hendaknya dipungut pada saat yang paling baik, yaitu pada saat yang paling dekat dengan diterimanya pendapatan/penghasilan yang dikenakan pajak. Sedangkan untuk pembayaran Pajak Kendaraan bermotor pemungutan pajaknya yaitu sesuai dengan tanggal pada saat pembelian kendaraan bermotor tersebut.

4. Sedangkan asas yang terakhir adalah Economic of Collections, dalam asas ini dijelaskan mengenai effisiensi penggunaan pajak itu sendiri, di mana asas ini lebih kepada yang menggunakan pajak yang telah diperoleh dalam hal ini pemerintah. Agar lebih berhati- hati dengan mengadakan pengeluaran pembiayaan yang dihasilkan dari peneriamaan pajak

\section{Dampak Pengenaan Tarif Pajak Progresif}

Tabel 3 Perbandingan Realisasi Penerimaan PAD Tahun Anggaran 2011, 2012 dan Tahun Anggaran 2013 UPTD Manado

\begin{tabular}{clll}
\hline Bulan & $\mathbf{2 0 1 1}$ & $\begin{array}{l}\mathbf{2 0 1 2} \\
(\mathbf{R p})\end{array}$ & $\begin{array}{l}\mathbf{2 0 1 3} \\
\mathbf{( R p )}\end{array}$ \\
\hline Januari & $7,207,932,200$ & $11,087,908,025$ & $21,273,414,400$ \\
Februari & $5,605,505,000$ & $15,745,354,700$ & $20,358,530,080$ \\
Maret & $6,869,095,000$ & $18,707,279,400$ & $19,319,722,300$ \\
April & $6,751,783,150$ & $16,747,267,800$ & $21,374,236,900$ \\
Mei & $6,970,219,650$ & $18,932,228,200$ & $25,763,017,900$ \\
Juni & $6,487,125,965$ & $17,860,262,300$ & $18,903,533,400$ \\
Juli & $7,220,682,700$ & $19,327,774,139$ & $23,456,859,200$ \\
Agustus & $6,991,777,407$ & $16,421,717,500$ & $19,561,461,300$ \\
September & $8,751,133,500$ & $17,073,330,700$ & $20,538,502,758$ \\
1Oktober & $7,272,148,900$ & $20,042,811,500$ & - \\
November & $7,767,711,375$ & $19,263,223,050$ & - \\
Desember & $7,085,161,400$ & $16,353,566,016$ & - \\
\hline
\end{tabular}

Sumber : Hasil olahan penulis

Perbandingan di atas dapat di lihat pada tahun 2011 di mana jumlah realisasi penerimaan PAD sepanjang tahun 2011 hanya berada dikisaran di bawah 10 milyar, pada tahun 2012 yang merupakan tahun awal pemberlakuan tarif pajak progresif telah mengalami peningkatan penerimaan pada kisaran 20 milyar. Namun jika dibandingkan dengan penerimaan pada hampir sepanjang tahun 2013 penerimaan meningkat drastis. Hal ini disebabkan pada tahun 2012 telah diberlakukannya pajak progresif, tetapi belum efektif dan maksimal seperti pada tahun 2013 yang kisaran penerimaan mencapai 25 milyar. Dapat dilihat juga chart diagram yang bersifat fluktuatif karena tidak semua kendaraan bermotor dikenakan pajak progresif, seusai UU dan Perda hanya kendaraan kedua dan seterusnya yang dikenakan pajak progresif. Kendaraan pertama masih dikenakan tarif normal yaitu $1,5 \%$.

Perbandingan beberapa perbandingan yang telah di sajikan dan dibahas di atas, dapat dilihat dampak yang dapat dirasakan yaitu meningkatnya penerimaan PAD yang nantinya akan diolah untuk pembangunan Daerah. 
Tabel 4 Perbandingan Jumlah Kendaraan dan Penerimaan PKB dan BBN-KB pada Bulan Januari, Februari dan Maret di Tahun Anggaran 2012 dan 2013

\begin{tabular}{lrcrl}
\hline & \multicolumn{2}{c}{2012} & \multicolumn{2}{l}{$\mathbf{2 0 1 3}$} \\
\hline Bulan & $\begin{array}{c}\text { Jumlah } \\
\text { Kendaraan } \\
\text { Bermotor }\end{array}$ & $\begin{array}{c}\text { Penerimaan } \\
\text { PKB }\end{array}$ & $\begin{array}{c}\text { Jumlah } \\
\text { Kendaraan } \\
\text { Bermotor }\end{array}$ & $\begin{array}{l}\text { Penerimaan } \\
\text { PKB dan } \\
\text { BBNKB }\end{array}$ \\
\hline Januari & 10.119 & 11.075 .889 .325 & 11.756 & 20.438 .693 .400 \\
Februari & 505 & 3.514 .214 .600 & 10.790 & 21.358 .530 .080 \\
Maret & 11.441 & 18.697 .279 .400 & 11.441 & 18.697 .279 .400 \\
\hline (Sumber $:$ Hasil Olahan Penulis & & &
\end{tabular}

Tabel 5 Presentase Perubahan Jumlah Kendaraan Bermotor dan Penerimaan PKB dan BBNKB Tahun 2012 ke Tahun 2013

\begin{tabular}{lcc}
\hline & Jumlah Kendaraan & $\begin{array}{c}\text { Penerimaan PKB dan } \\
\text { BBNKB }\end{array}$ \\
\hline Januari & $16,80 \%$ & $84 \%$ \\
Februari & $2036,63 \%$ & $507,77 \%$ \\
Maret & $0 \%$ & $0 \%$ \\
\hline
\end{tabular}

(Sumber : Hasil Olahan Penulis)

Tabel 4 dan tabel 5 merupakan sampel dari perbandingan Jumlah Kendaraan Bermotor dan Jumlah Penerimaan PKB dan BBNKB serta persentase perubahannya yang terjadii pada tahun 2012 sampai 2013. Dari kedua tabel di atas dapat diketahui kecenderungan jumlah kendaraan bermotor dari tahun ke tahun meningkat dengan presentase pada bulan januari Tahun 2012 ke 2013 sebesar 16,17\% yang membuat penerimaan PKB dan BBNKB meningkat sebesar $84 \%$, pada bulan februari dapat di lihat terjadi lonjakan jumlah kendaraan pada 2013 sebesar 2036,63\% tetapi disertai dengan menurunnya jumlah kendaraan yang membayar PKB dan BBNKB pada bulan Februari tahun 2012 yaitu sebesar 507,77\%. Kemungkinan besar hal ini terjadi disebabkan perpindahan kendaraan ke daerah lain atau terjadi penunggakan pembayaran PKB. Namun pada bulan Maret 2012 dan bulan Maret 2013 tidak terjadi perubahan apapun atau presentase perubahan 0\%. Dari hasil perbandingan tersebut dapat disimpulkan bahwa tujuan awal pemerintah menerapkan atau memberlakukan tarif pajak progresif ini sangat sesuai dengan fungsi pajak yaitu Fungsi Budgetair yang adalah pajak digunakan untuk membiayai keperluan rumah tangga negara, dalam hal ini dengan menerapkan tarif pajak progresif pemerintah dapat meningkatkan penerimaan PAD yang nantinya akan digunakan untuk membiayai keperluan rutin negara.

\section{PENUTUP}

\section{Kesimpulan}

Penulis dapat menyimpulkan beberapa hal, yaitu sebagai berikut :

1. Pengenaan pajak progresif sesuai dengan UU No. 28 tahun 2009 dan Perda Sulawesi Utara No 7 tahun 2011.

2. Sebelum pengenaan pajak progresif wajib pajak yang mempunyai kendaraan bermotor lebih dari satu, masing kendaraan yang dimiliki dikenakan tarif yang sama yaitu $1.5 \%$. Sedangkan sesudah pengenaan, masing- masing kendaraan kedua dan seterusnya dikenakan tarif $2 \%$ dan seterusnya. 
3. Pemberlakuan Tarif Pajak Progresif di Kota Manado mulai diberlakukan pada tahun 2012 meskipun masih belum efektif dan masih terus melakukan penyesuaian terhadap aturan baru tersebut. Efektivitas pemberlakuan pajak progresif terjadi pada tahun 2013.

4. Pengenaan pajak progresif masih sangat sesuai dengan "The Four Maxims"yaitu asas pemungutan pajak yang dikemukakan oleh Adam Smith yang terdiri dari kesamaan dan keseimbangan (Equality), kepastian hukum (certainty); (c) asas tepat waktu (convenient of payment); dan (d) asas economic of collection.

5. Pengenaan pajak progresif pada awalnya diharapkan dapat berdampak baik yaitu untuk menekan laju peningkatan volume kendaraan yang dapat mengakibatkan kemacetan dan ketidaknyamanan di jalan raya. Namun seiring dengan berjalan pengenaannya, pajak progresif memiliki dampak positif lainnya yaitu meningkatkan penerimaan PKB dan BBNKB yang dengan otomatis meningkatkan penerimaan PAD yang sebagian besar memang merupakan sumber dari Pajak Daerah.

6. Pengenaan Tarif Pajak Progresif sudah berjalan sebagaimana tujuan awal pemerintah memberlakukannya dan sangat sesuai dengan fungsi pajak yaitu Fungsi Budgetair.

\section{Saran}

Penulis ingin memberikan saran pada pihak yang terkait dengan pemberlakuan pajak progresif ini.

1. Perlu diadakan penyuluhan dan seminar atau pemberitahuan melalui media cetak maupun elektronik. Agar para wajib pajak dapat mengerti dan menerima dengan baik pemberlakuan aturan baru ini.

2. Tidak hanya masyarakat yang perlu memahami tentang pajak progresif ini, para pegawai pemerintah yang terkait pun perlu memahami dengan baik agar dapat memberikan penjelasan yang memuaskan pada wajib pajak yang bertanya.

3. Dengan meningkatnya pembayaran pajak kendaraan bermotor perlu juga diimbangi dengan upaya peningkatan pelayanan pemerintah di Kantor Samsat maupun di dinas- dinas terkait. Seperti kenyamanan dalam mengantri, menambah loket kasir dan loket konsultasi.

\section{DAFTAR PUSTAKA}

Fajriani. 2013. Pengenaan Tarif Pajak Progresif pada Kendaraan Bermotor berdasarkan " The Four Maxims". Jurnal Vol 1 No 2. Universitas Surabaya. Surabaya.Http://ejournal.unesa.ac.id/index.php/jurnalakuntansi/article/view/739/baca-artikel. Diakses 28 Agustus 2013.

Mardiasmo. 2009. Perpajakan. ANDI. Yogyakarta.

Mardiasmo. 2011. Perpajakan. ANDI. Yogyakarta.

Muljono. Djoko. 2009.Ketentuan Umum Perpajakan. ANDI. Yogyakarta.

Nugraha. Haris. 2010. Penerapan Pajak Progresif terhadap Wajib Pajak Kendaraan Bermotor berdasarkan peraturan daerah Jawa Timur Nomor 9 Tahun 2010 tentang Pajak Daerah. Jurnal Ilmiah. Universitas Brawijaya. Malang.http://hukum.ub.ac.id/wp-content/uploads/2013/01/Jurnal-Harist-Agung-Nugraha0810113287.pdf. Diakses 28 Agustus 2013.

Republik Indonesia. Undang-Undang Republik Indonesia Nomor 16 Tahun 2000 tentang Ketentuan Umum dan Tata Cara Perpajakan sebagaimana diubah dengan Undang- Undang Nomor 28 Tahun 2007. Jakarta

Republik Indobesia Undang-Undang Republik Indonesia Nomor 28 Tahun 2009 tentang Pajak Daerah dan Retribusi Daerah. Jakarta

Republik Indonesia. Peraturan Daerah Provinsi Sulawesi Utara Nomor 7 Tahun 2011 tentang Pajak Daerah Provinsi Sulut. Manado

Sugiyono. 2009.Metode Penelitian Kuantitatif. Kualitatif Dan RD. Alfabeta. Bandung.

Waluyo. 2011.Perpajakan Indonesia. Edisi 10. Salemba Empat. Jakarta. 